Piotr Madajczyk

Joanna Szymoniczek

\title{
WYDARZENIA 1968 ROKU NA ZACHODZIE W POLSKICH MEDIACH
}

Celem niniejszego artykułu jest pokazanie, w jaki sposób potrzeby polityki zagranicznej i wewnętrznej autorytarnego państwa, jakim była PRL, prowadziły do deformacji w mediach obrazu wydarzeń 1968 roku. W systemie PRL nie tylko obowiązywała cenzura, ale ponadto reżim dokładnie określał, o jakich tematach należy pisać, a o jakich nie, jakich problemów mogą dotyczyć ukazujące się artykuły, a które można wspomnieć małym drukiem w rubryce o wydarzeniach na świecie. Tym samym istniały daleko idące możliwości kreowania dla czytelnika obrazu świata, który dość istotnie różnił się od rzeczywistości.

Przyjrzyjmy się dokładniej, jakie były priorytety ówczesnej polskiej polityki, którym musiał odpowiadać przekaz medialny.

\section{Polska polityka zagraniczna i wewnętrzna}

Od połowy lat sześćdziesiątych XX wieku pogarszały się stosunki Polski ze Stanami Zjednoczonymi. Waszyngton coraz silniej zaangażowany był w kryzys w Indochinach, w czerwcu 1967 roku eskalował konflikt na Bliskim Wschodzie. Narastały problemy wewnętrzne w Stanach Zjednoczonych $\mathrm{w}$ formie rosnącej fali protestów przeciw wojnie w Wietnamie i ruchu protestu przeciw dyskryminacji rasowej (Martin Luther King). Nasilała się w polskich mediach krytyka Stanów Zjednoczonych przez władze polskie jako państwa łamiącego zasady demo- 
kracji, w którym panuje rasizm i rządzą tajne służby. Minister Adam Rapacki mówił w wywiadzie dla "Trybuny Ludu” o dominacji w USA zwolenników polityki z pozycji siły ${ }^{1}$.

Drugim państwem postrzeganym negatywnie była RFN, a celem polskiej polityki zagranicznej było blokowanie nawiązania z nią kontaktów dyplomatycznych przez inne państwa bloku wschodniego. Podczas posiedzenia Doradczego Komitetu Politycznego Układu Warszawskiego w dniach 4-5 lipca 1966 roku w Bukareszcie ustalono warunki konieczne dla nawiązania stosunków z RFN: odwołano się do nienaruszalności granic, w tym polskiej granicy zachodniej i między dwoma państwami niemieckimi. Po raz pierwszy państwa bloku wschodniego sformułowały wspólne zasady polityki wobec Niemiec, aczkolwiek dyplomaci polscy przypuszczali, że poszczególne kraje nie będą ich przestrzegać. Z niepokojem obserwowano politykę Pragi ${ }^{2}$. Największy problem dla polskiej dyplomacji stanowiła polityka Bukaresztu, gdyż dostrzegano rosnące zainteresowanie Rumunii rozbudowaniem stosunków politycznych i współpracy gospodarczej z RFN. Przywódca rumuński przeciwstawiał się ponadto próbom wzmocnienia integracji w ramach RWPG, krytykował propozycje tworzenia $\mathrm{w}$ jej ramach współpracy wielostronnej, w której nie będą uczestniczyć wszystkie państwa członkowskie ${ }^{3}$.

Ponieważ Polska nie miała możliwości wywarcia presji na inne państwa bloku wschodniego, Gomułka naciskał na władze sowieckie, aby podjęły inicjatywę zwołania narady ministrów spraw zagranicznych w celu dalszego omówienia zasad polityki wobec Niemiec. Sam nie blokował możliwości rozmów polsko-zachodnioniemieckich, proponując RFN kontakty na szczeblu ministerstw. 18 stycznia 1967 roku Breżniew spotkał się podczas nieoficjalnej wizyty z Gomułką w Łańsku. Gotów

\footnotetext{
1 „Trybuna Ludu”, 1 stycznia 1967. Ambasadorem PRL od września 1967 roku był Jerzy Michałowski, dyplomata o dużym doświadczeniu: 1945-1946 ambasador w Londynie, 1955-1956 aktywny w Międzynarodowej Komisji Nadzoru i Kontroli w Wietnamie, 1956-1960 Stały Przedstawiciel przy ONZ.

2 W. Jarząbek: „Ulbricht-Doktrin” oder "Gomutka-Doktrin”? Das Bemühen der Volksrepublik Polen um eine geschlossene Politik des kommunistischen Blocks gegenüber der Westdeutschen Ostpolitik 1966/67, "Zeitschrift für Ostmitteleuropa-Forschung (ZFO)“ 2006 (55), z. 1, s. 79-115, tutaj s. 92-95.

3 Informacja tłumaczona z rosyjskiego, z 18 maja lub czerwca (błędnie wpisane: $\mathrm{Y}$ ) 1966, Archiwum MSZ (dalej: AMSZ) 1/77.
} 
był zaakceptować podjęcie przez państwa bloku rozmów z RFN, natomiast Gomułka niezmiennie podkreślał konieczność uwzględnienia wspominanych już polskich warunków. Wbrew naciskom Warszawy i Berlina Wschodniego Rumunia nawiązała 31 stycznia 1967 roku stosunki dyplomatyczne z Bonn ${ }^{4}$. Doprowadziło to do napięć z NRD, a w dniach 8-10 lutego odbyła się kolejna konferencja ministrów spraw zagranicznych Układu w Warszawie. Gomułka dodał w jej trakcie do sformułowanych wcześniej warunków uznanie układu monachijskiego za nieważny od początku jego zawarcia. Pozycja Gomułki była na tyle silna, że warunki te zostały zaakceptowane ${ }^{5}$.

Aczkolwiek warunek uznania NRD pozornie najbardziej odpowiadał interesom tego państwa, forsował go Gomułka, uważając za konieczny w sytuacji, gdy coraz więcej krajów bloku wschodniego zaczynało dążyć do nawiązania stosunków dyplomatycznych, a szczególnie gospodarczych z RFN ${ }^{6}$. Przyjął, że ważniejsze jest wysunięcie go przed warunek uznania granicy na Odrze i Nysie Łużyckiej. Gwarancją granicy był bowiem przede wszystkim ZSRR, a uznanie NRD było nie do przyjęcia dla RFN i skutecznie blokowało ofensywną zachodnioniemiecką politykę zagraniczną.

Gomułka uważał poparcie Polski dla NRD za na tyle ważne, iż spowoduje wschodnioniemieckie otwarcie na polskie propozycje intensyfikacji współpracy gospodarczej. ${ }^{7}$ Jednak w listopadzie 1967 roku władze NRD wycofały się z dokonanych ustaleń w zakresie dalej idącego skoordynowania gospodarek obydwu państw. Zasłaniały się obiektywnymi trudnościami ekonomicznymi, ale widać było, że decyzja ta ma przede wszystkim znaczenie polityczne ${ }^{8}$.

${ }^{4}$ Winiewicz w rozmowie z Gronouskim nie był tym zaskoczony, wskazywał na odmienną historię stosunków niemiecko-rumuńskich. Mówił o Bułgarii i Węgrzech jako "the next likely candidates" do nawiązania stosunków dyplomatycznych z RFN (D.J. Allen: The Oder-Neisse Line - the United States, Poland and Germany in the Cold War, Westport 2003, s. 258.

Jarząbek: „Ulbricht-Doktrin”..., s. 96-97; D. Selvage: Polska - NRD. „Doktryna Ulbrichta" w świetle dokumentów, „Rocznik Polsko-Niemiecki” 1995, nr 3, s. 77-105, tutaj s. 78-80. Według Jarząbek odniesienie do układu monachijskiego zostało wprowadzone, żeby uniknąć wrażenia, iż problemem są jedynie relacje PRL - RFN.

6 Selvage: op. cit., s. $78-84$.

7 Ibidem, s. 84 i n.

8 Por. M. Tomala: "Przyjaźń" z Niemiecka Republika Demokratyczna, ale za jaka cene, „Rocznik Polsko-Niemiecki” 1995, nr 3, s. 58-75, tutaj s. 71-75. 
Tymczasem dyplomacja zachodnioniemiecka zaczęła wychodzić z impasu. W roku 1967 zostały nawiązane stosunki dyplomatyczne RFN-Rumunia, rok później wznowiono stosunki z Jugosławią. Zwiększała się aktywność dyplomatyczna skierowana na Czechosłowację i Węgry. Zachodni partnerzy pozytywnie oceniali zachodnioniemiecką gotowość do rozmów ${ }^{9}$.

Brak elastyczności polityki polskiej ograniczał jej skuteczność wobec Francji i RFN. Widoczne to było podczas wizyty w dniach 6-12 września 1967 prezydenta Francji Charlesa de Gaulle'a w Polsce. Polskie oczekiwania szły początkowo bardzo daleko, przygotowywano projekt polsko-francuskiego układu o przyjaźni i współpracy, włączając doń rozbudowę kontaktów gospodarczych, naukowo-technicznych i kulturalnych. Przewidywano polityczne konsultacje oraz dążenie do nienaruszalności „ustalonych i istniejących” granic. W ostatecznej odpowiedzi, która nadeszła za pośrednictwem fancuskiego ambasadora, przekazano, że propozycje byłyby sprzeczne z francuską polityką porozumienia wszystkich państw europejskich. Minister Rapacki podkreślał znaczenie wizyty jako potwierdzenia obecności Francji w tym regionie Europy i odnowienia przyjaźni polsko-francuskiej. De Gaulle w swoich wypowiedziach wyrażał akceptację Polski w ramach istniejącego ustroju, wskazywał na zbieżność poglądów w tak podstawowych sprawach polityki międzynarodowej jak Indochiny. Rozbieżności pozostały w odniesieniu do problemu niemieckiego, aczkolwiek Gomułka i de Gaulle przeciwni byli nuklearnym zbrojeniom RFN. Gość podkreślał, że Francja uznaje polską granicę zachodnią za nienaruszalna, odwiedził ziemie zachodnie. Nie otrzymano natomiast żadnych zapewnień co do NRD, gdyż nie uległo zmianie negatywne stanowisko francuskie wobec Niemiec Wschodnich jako państwa niebędącego wyrazem woli narodu niemieckiego. Podzielone Niemcy postrzegane były przez Paryż jako element zamętu, wygodny dla USA i ZSRR. Wprawdzie de Gaulle obawiał się wzrostu potęgi Niemiec, ale widział inne rozwiązanie ich problemu - w ramach europejskich. Nie odrzucał zjednoczenia Nie-

\footnotetext{
9 O pozytywnych opiniach brytyjskich M. Tomala: Warszawa - Berlin - Bonn (1944-1980), Szczecin 1987, s. 250.
} 
miec dokonanego w zgodzie z innymi państwami ${ }^{10}$. Ogólnie biorąc, wizyta ożywiła relacje polsko-francuskie, prezydent Francji wielokrotnie podkreślał tradycje polsko-francuskich kontaktów i swoją sympatię dla Polski. Nie wprowadziła do nich natomiast istotnych zmian.

Powyższemu układowi międzynarodowemu odpowiadał opis wydarzeń w prasie polskiej.

\section{Pierwszy bohater negatywny - Stany Zjednoczone}

Zainteresowanie polskich mediów Stanami Zjednoczonymi było już znaczne we wcześniejszych latach. Nie inaczej było w 1968 roku. Dominowały negatywne informacje, które można było wykorzystać propagandowo, przede wszystkim dotyczące amerykańskiej polityki zagranicznej. Eksponowano zwłaszcza wojnę w Wietnamie, szczególnie gdy Amerykanie popełniali zbrodnie, przegrywali bitwę, ponosili duże starty w ludziach. Informacjom zazwyczaj towarzyszyły drastyczne obrazy z państw azjatyckich czy Ameryki Łacińskiej, przedstawiające ogrom nędzy i rozpaczy w tych państwach, za które, zdaniem autorów, odpowiadały przede wszystkim Stany Zjednoczone i ich imperialistyczna polityka. Miało to je dyskredytować, podobnie jak szkolenie specjalnych oddziałów i tłumienie wyzwoleńczych ruchów w Ameryce Łacińskiej - Gwatemali i Boliwii ${ }^{11}$ czy starannie odnotowywane protesty i demonstracje w kolejnych państwach, jako państwo powołane do dania światu pokoju, co jak same podkreślały było ich misją ${ }^{12}$. W relacjach prasowych koncentrowano się także na amerykańskim wsparciu dla Izraela ${ }^{13}$.

${ }^{10}$ Bardzo krytycznie ocenia wizytę M. Pasztor: Między Paryżem, Warszawa i Moskwa, Toruń 2003, s. 116-121. Też W. Jarząbek: Rozmowa w cztery oczy między generałem Charles'em de Gaulle'em i Władysławem Gomułka, „Polski Przegląd Dyplomatyczny” 2005, t. 5, nr 2 (24), s. 147-167, tutaj s. 148 i n.

${ }^{11}$ Archiwum Telewizji Polskiej (dalej: A TVP), sygn. F 7804, Che Guevara...; ibidem sygn. F 913, Przeglad roku 1968. Zbiory Archiwum Telewizji Polskiej, podobnie jak Polskiego Radia, są niekompletne. Na podstawie dostępnych informacji niemożliwe jest ustalenie, jaką część stanowią zachowane materiały, czego brakuje itp. Dodatkowo w części materiałów brakuje informacji bibliograficznych, takich jak rok i miejsce produkcji, nazwisko reżysera, scenarzysty, producenta, a czasem nawet tytułu.

${ }^{12}$ A TVP, sygn. Zarch. 68201, Demonstracje studentów w Japonii, USA i Korei przecizko wojnie i rasizmowi. s. 1.

${ }^{13}$ Pierwsze samoloty z USA dla armii izraelskiej, „Życie Warszawy”, 18 czerwca 1968, 
Krytyczne artykuły były na różnym poziomie, niekiedy w formie prymitywnej propagandy, a niekiedy - wykorzystania dobrych, ale krytycznych wobec polityki amerykańskiej, tekstów Edmunda Osmańczyka. Wskazywał on w nich na nieadekwatność amerykańskiej polityki $\mathrm{w}$ stosunku do wielkich wyzwań, próby siłowej realizacji dominacji nie tylko na Atlantyku, ale też na Pacyfiku i Oceanie Indyjskim ${ }^{14}$.

Równie krytycznie oceniano politykę wewnętrzną. Rok 1968 to przede wszystkim zabójstwa: Martina L. Kinga i Roberta Kennedy'ego. Obydwa wykorzystano w celu wzmocnienia krytyki Stanów Zjednoczonych. Pierwsze relacje po zamordowaniu Martina L. Kinga skupiały się początkowo na informowaniu o przebiegu samej zbrodni ${ }^{15}$, a następnie pogrzebu, z którego obszerne fragmenty, m.in. wystąpienie dyrektora Morehouse College w Atlancie Benjamina Maysa, odśpiewanie pieśni We shall overcome czy ostatnie kazanie Kinga, nadawało Polskie Radio. Relacjom towarzyszyły informacje o zamieszkach i demonstracjach w amerykańskich miastach, jakie wybuchły po zamordowaniu pastora. Skrupulatnie podawano liczbę zabitych, rannych i aresztowanych oraz dane o stratach i zniszczeniach ${ }^{16}$. Wydarzenia te trafily na pierwsze strony gazet, z których krzyczały ostro sformułowane tytuły. Najczęściej używanym określeniem w tym kontekście była hańba lub haniebny mord. Zabójstwo to służyło do podjęcia dyskusji o dyskryminacji, rasizmie i sytuacji ludności czarnoskórej w Stanach Zjednoczonych ${ }^{17}$.

Zainteresowanie widoczne po śmierci Kinga było niczym wobec sytuacji po zabójstwie Roberta Kennedy'ego. Była to przysłowiowa „woda na młyn" polskiej propagandy. Pierwsze relacje ze Stanów Zjednoczonych, początkowe jeszcze z hotelu Ambasador, następne ze Szpitala Dobrego Samarytanina w Los Angeles, nadeszły, gdy senator jeszcze żył1 ${ }^{18}$ Od początku nie skupiały się one na samej zbrodni. Oprócz informacji o przebiegu zamachu od razu znalazły się znaczące komentarze 1968.

${ }^{14}$ Por. E. Osmańczyk: Mos Pearl Harbour - Sydney - Tokio, „Polityka” nr 8, 24 lutego

${ }^{15}$ Dr Martin L. King zamordowany, "Życie Warszawy”, 6 kwietnia 1968, s. 1.

${ }^{16}$ Stany Zjednoczone w ogniu rozruchów, "Życie Warszawy”, 7 kwietnia 1968, s. 1.

${ }^{17}$ Archiwum Polskiego Radia (dalej: A PR), sygn. 3211 poz. 1, 7 dni w kraju i na świecie z 14 kwietnia 1968 roku; tamże Kawalkada czasu 1964-1974 cz. 2: śmierć Martina Luthra Kinga; tamże sygn. EF 4666, Pogrzeb Martina Luthra Kinga.

${ }_{18}$ Zamach na Roberta Kennedy'ego, "Życie Warszawy”, 6 czerwca 1968, s. 1-2. 

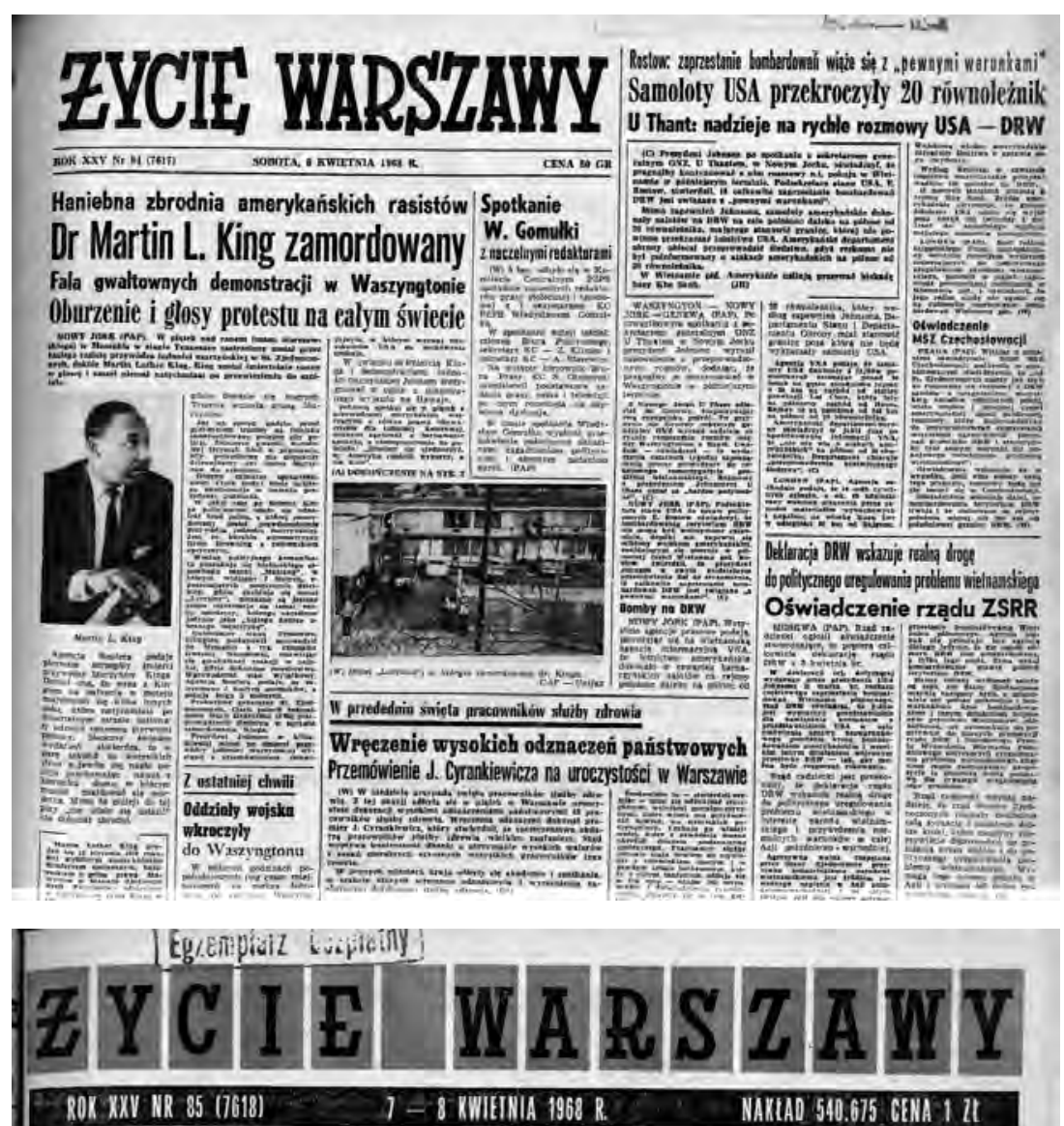

talaba narodowa po haniebnym zamordowaniu pastora Kinga

Rozwiną́c szerok̨ publiczną dyskusję

St. Zjednoczone w ogniu rozruchów Zabici - ranni - tysiące aresztowanych -

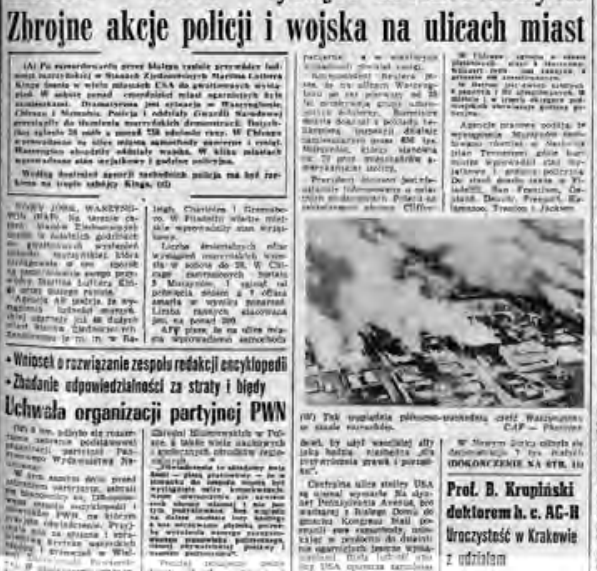

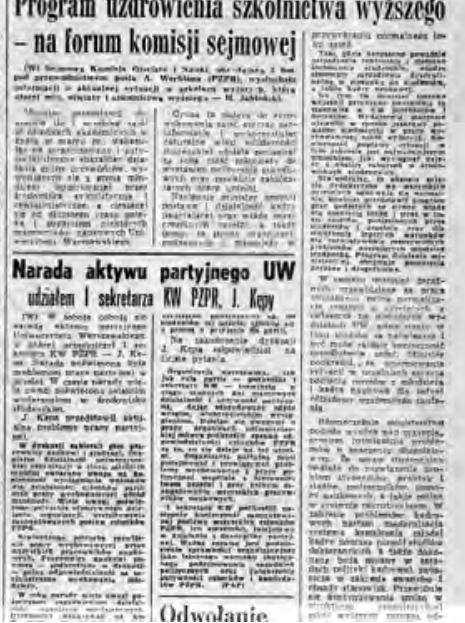




\section{EYCIE WARS'ZAWY

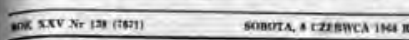

Zbrodniczy cios fragicznym dowodem glębokiej degeneracji życia politycznego USA Disis pogrzeb Roberta Kennedy'ego w Waszyngionie Itastera strachu * Spisek na izycie senatora? * Ko jest odpowiedzialny zo zbrodiei?

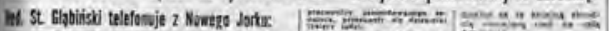

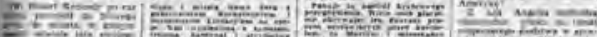

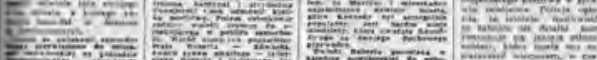
$\frac{1}{1+5}=3$

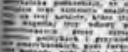

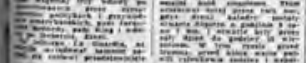
hasc i wspolpraca gospodarcza $z$ DRW Modpisanie porozumienia w Warszawie

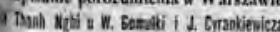
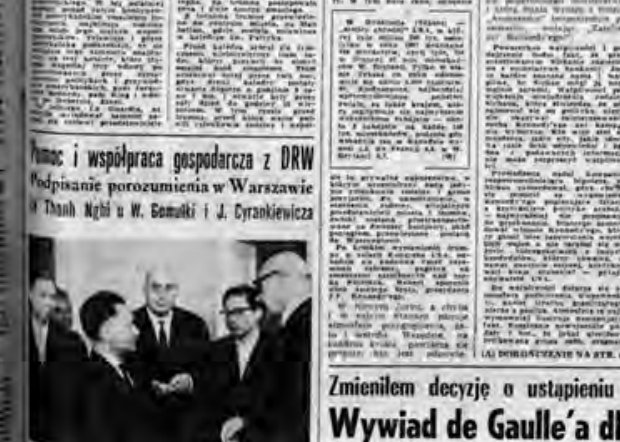

"Literatura polska w sluźbie socjalistyemej ojeryzay" Obrady XI Zjazdu Pisarzy Ziem Zachodnich i Pólnocnych Przemówienie E. Gierka w Kałowicach ñ

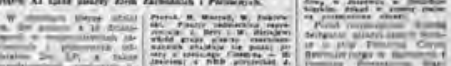

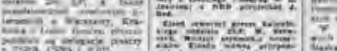

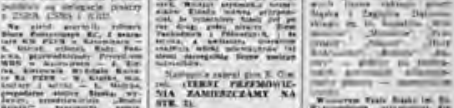
$2=2-4$ and Konkurs Konkurs Razem"

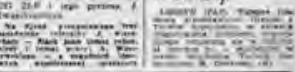
46 pahstw - 6 tys. wystawe 6 w - Modernizacja ekspozycji Jutro otwarcie XXXVII MTP

Zmienilem decrije o ustapieniu ze stanowiska... Wywiad de Gaulle'a dla radia i TV
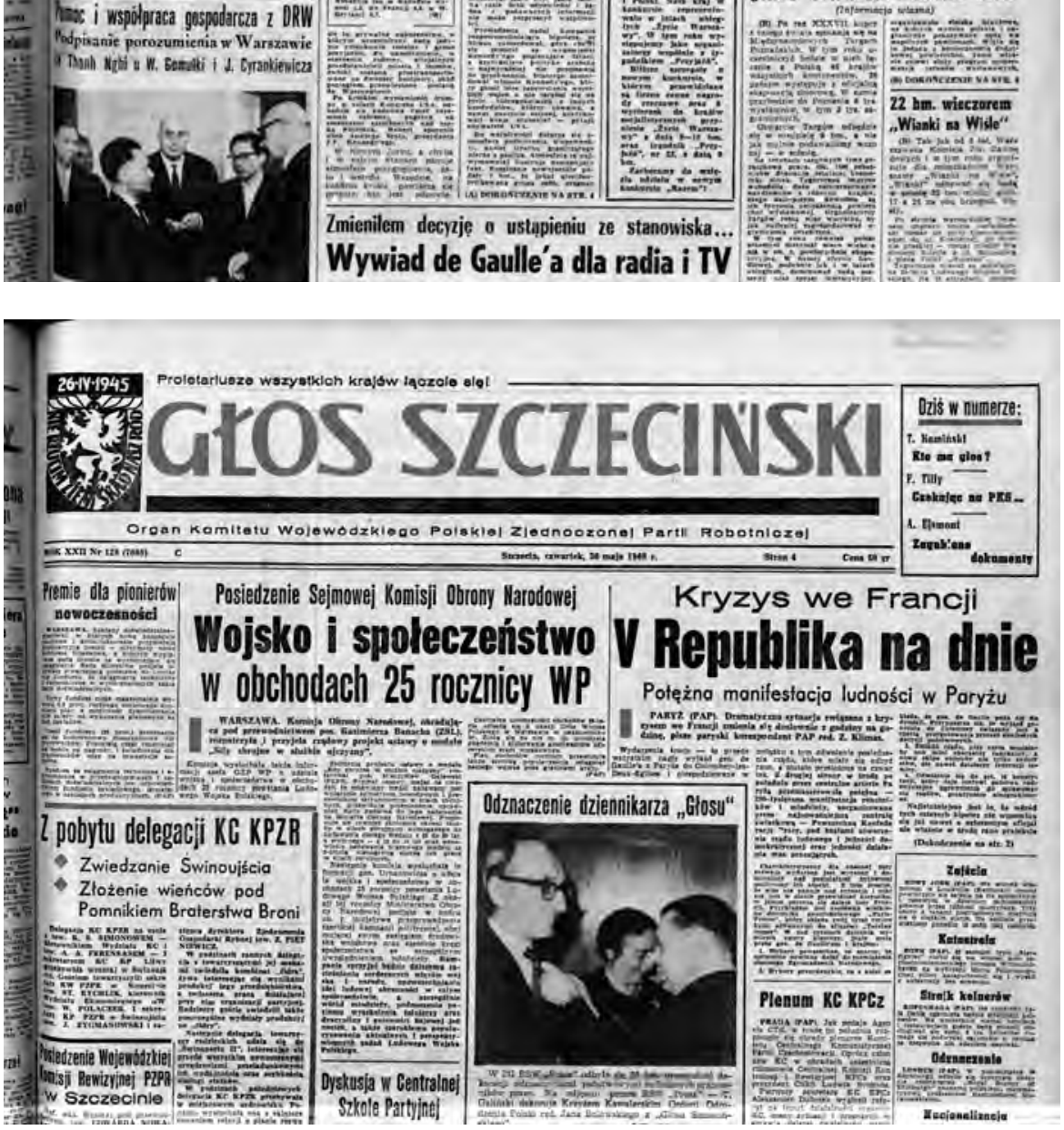
i oceny tego, co się stało. Nasiliły się one po śmierci Kennedy'ego ${ }^{19}$. Obszerne relacje $\mathrm{z}$ uroczystości, w których przywoływano fragmenty ostatniego przemówienia wygłoszonego przez senatora po kolejnym zwycięstwie w prawyborach w Kalifornii, okraszone były druzgoczącą krytyką Ameryki ${ }^{20}$. W podobnym tonie wypowiadali się z korespondenci TVP i RP z Bonn, Moskwy i Pragi, którzy korzystając z czasu antenowego przedstawiali polską opinię na temat zbrodni, zamiast reakcji innych społeczeństw na to zabójstwo ${ }^{21}$.

Kolejna zbrodnia była doskonałą okazją do przedstawienia społeczeństwu polskiemu sytuacji w USA. Stworzono więc szereg programów radiowych i telewizyjnych, a w prasie prezentowano opracowania, w których redaktorzy i zaproszeni goście dyskutowali na temat tych zbrodni, starając się je wyjaśnić. Rozmowy szybko zamieniały się w totalną pod każdym możliwym względem, krytykę Stanów Zjednoczonych. Wskazywano, że w kraju tym mamy do czynienia z poważnym kryzysem zarówno ekonomicznym, politycznym, społecznym, jak i moralnym. Widzimy zagubione społeczeństwo, w którym zerwane zostały wszystkie więzi międzyludzkie, gdzie człowiek jest samotny w tłumie, rozwiązuje swoje problemy za pomocą siły i agresji. Stąd nie tylko powszechny wzrost przestępczości, zwłaszcza morderstw i zabójstw, ale i rozwiązywanie sporów politycznych za pomocą broni. A ta od zawsze była kojarzona w Ameryce z męskością, siłą i władzą, czego dowodem jest kultura masowa. Jeśli to tego doda się pewną tradycję, polegającą na swoistym prawie do gwałtu (biali mordowali Indian, wcześniejsze zabójstwa polityków, np. A. Lincolna czy J. F. Kennedy'ego), nie należy dziwić się temu, co się stało. W Stanach Zjednoczonych jest odpowiedni klimat do takiego postępowania. Jeśli w agresywny sposób prowadzi się politykę zagraniczna, czego dowodem jest postępowanie Amerykanów w Wietnamie i Ameryce Południowej, to prędzej czy później musiało dojść do przeniesienia takich zachowań do wnętrza kraju. Do-

\footnotetext{
${ }^{19}$ Robert Kennedy nie żyje, "Życie Warszawy”, 7 czerwca 1968, s. 1.

${ }^{20}$ Dziś pogrzeb Roberta Kennedy'ego w Waszyngtonie, "Życie Warszawy”, 8 czerwca 1968, s. 1-2.

${ }^{21}$ A TVP, sygn. F 913, Przeglad roku 1968; A PR, sygn. 5548 poz. 3, 7 dni w kraju i na świecie; tamże sygn. 3118/1, Relacja o przebiegu morderstwa Roberta Kennedy'ego, ibidem, sygn. 3118/2, Echa zbrodni na Robercie Kennedym.
} 
tąd Amerykanie za bardzo zajmowali się innymi, a powinni być soba, bo to, co się stało, jest dowodem na faszyzację Ameryki. Dodatkowo nie należy oczekiwać walki z gangsterami, ponieważ spowodowałoby to kryzys całej struktury ekonomicznej, która oparta jest na mafii, z którą powiązani są najważniejsi politycy w państwie. Wiedząc o tym, niezrozumiała jest sympatia, jaką ma wiele narodów, w tym Polacy, dla Amerykanów ${ }^{22}$.

Podsumowując wnioskowano, że Stany Zjednoczone nie są państwem demokratycznym. Przede wszystkim potępiano je, a nie prezentowano głębszych analiz, umożliwiających zrozumienie dokonujących się w nich procesów.

\section{Drugi bohater negatywny - Niemcy Zachodnie}

Drugim negatywnym bohaterem była RFN. Prasa zamieszczała sporo przypomnień o II wojnie światowej, nawiązań do rewizjonistycznej polityki powojennej. RFN prezentowana była jako państwo militarystyczne, pragnące posiadać broń atomową i rakiety, naciskające partnerów zachodnich na zbrojenia i blokujące rozbrojenie ${ }^{23}$. RFN razem z Izraelem i USA, wobec konfliktu w Wietnamie i na Bliskim Wschodzie doprowadziły do eskalacji napięcia. W RFN zwalczano lewicę, policja prześladowała KPD (Kommunistische Partei Deutschland), a na sile zyskiwali naziści (NPD) ${ }^{24}$. Polska nie mogła mieć do tego państwa zaufania, szczególnie wobec obsesji Bonn na punkcie zjednoczenia Niemiec. Dodatkowo wrogość władz polskich wzmocniły protesty w RFN przeciw zwolnieniu kilku profesorów z UW po Marcu $1968^{25}$.

${ }^{22}$ A TVP, sygn. F 1332, Parch. 6927, Gang, gangster, gangsterstwo, program Lidii i Jerzego Green; ibidem, sygn. F 1332, Parch. 369, Zabójstwo J.F. Kennedy'ego, A PR sygn. PZ 30742, Zbrodnia, która wstrząsnęła opinia światowa.

${ }^{23}$ Z. Bagiński: Bundesmarine i rakiety, „Polityka” 1968, nr 8 z 24 lutego, s. 10.

24 Por. H. Hartwig: NPD wyjaśnia..., „Polityka” 1968, nr 16 z 20 czerwca.

25 Protest skierował prof. A. Schwan, dyrektor Instytutu Suhra, „Znany z prawicowych poglądów Schwan nie miał odwagi protestować przeciwko zastrzeleniu przez policję zachodnioniemiecką jego studenta Ohnesorga, oburzał się na demonstracje przeciw wojnie wietnamskiej, jednak włączył się do antypolskiej kampanii inspirowanej przez władze Berlina zachodniego, „Polityka” 1968, nr 15 z 13 kwietnia, rubryka „Kraje kapitalistyczne". 
Kreślony był obraz narastających konfliktów społecznych w „krajach kapitalistycznych", obejmujących zarówno USA, RFN (po zamachu na Rudiego Dutschke), jak i strajki w Wielkiej Brytanii. „Stany Zjednoczone nie mają monopolu na mord polityczny. W Berlinie zachodnim dokonano zamachu na Rudi Dutschkego, przywódcę Socjalistycznego Związku Studentów Niemieckich" ${ }^{26}$. Zrozumienie istoty tego ruchu było w komentarzach drugorzędne. Ważne było jedynie kreowanie obrazu systemu represyjnego, tłumiącego przemocą wszelką opozycję. Temu służyło dokładne, emocjonalne i propagandowe relacjonowanie tego, co się działo w RFN: masowego sprzeciwu młodzieży, brutalnych metod policji, głuchych na argumenty niemieckich polityków. Przytaczano wypowiedzi polityków światowych, sprzeciwiających się takiej polityce Bonn. Powtarzanie haseł protestujących, takich jak „Nie chcemy więcej roku 1933” czy „W obronie demokracji”, jednakże często w oderwaniu od relacjonowania protestów, wywoływało u czytelników wrażenie, że nie jest to stanowisko protestujących w RFN, tylko innych, zagrożonych, społeczeństw. Jednak $\mathrm{w}$ radiu i telewizji temat zachodnioniemiecki zdecydowanie ustępował w 1968 roku innym wydarzeniom ${ }^{27}$.

Analizowane były w tygodniku „Polityka” wydarzenia we Francji, pokazywano kryzys sytemu, tło, przyczyny napięć. Brakowało podobnych tekstów o USA, RFN. W Niemczech Zachodnich sytuacja była jasna: przygotowywano ustawy wyjątkowe, aby wprowadzić Dyktature w majestacie prawa ${ }^{28}$. Ton tekstów był alarmujący, często histeryczny.

RFN pojawiała się $\mathrm{w}$ prasie polskiej jeszcze $\mathrm{w}$ jednym kontekście, w powiązaniu z zagrożeniami dla Czechosłowacji, co jest zrozumiałe

26 „Polityka” 1968, nr 16 z 20 kwietnia. O Dutschkem ukazały się dwa artykuły w „Polityce” (Strategia Blutwurstu nr 35 z 2 września 1967 i Lewica NRF nr 17 z 27 kwietnia 1968). Przedstawiono go jako członka ruchu lewicy. Eugeniusz Guz dał, jak sądzimy, w drugim z tych tekstów dobry przegląd zróżnicowanej palety różnych organizacji o lewicowej orientacji w RFN, podsumowując: „Nie kartoteki członkowskie stanowią dzisiaj o sile lewicowo-socjalistycznego nurtu w NRF, lecz przenikanie jego argumentów do całej opozycji pozaparlamentarnej, a także poza nią". Dostrzegał, że ta „lewica” nie ma oparcia w związkach zawodowych i zakładach pracy.

${ }^{27}$ Mimo intensywnej kwerendy w Archiwum Telewizji Polskiej i Polskiego Radia nie udało się odnaleźć żadnych materiałów dotyczących Niemiec w 1968 roku. W programach i audycjach informacyjnych, takich jak 7 dni w kraju i na świecie, temat Niemiec właściwie się nie pojawia.

${ }^{28}$ H. Zdanowski: Dyktatura w majestacie prawa, „Polityka” 1968, nr 27 z 6 lipca. 
ze względu na wspomniane wcześniej priorytety polskiej polityki zagranicznej.

Co zrozumiałe, wydarzenia $\mathrm{u}$ południowego sąsiada przyciągały uwage polskiej publicznej opinii. W styczniu informowano o dyskusjach toczących się w Czechosłowacji w związku z październikowym plenum Komunistycznej Partii Czechosłowacji (KPCz). Podkreślano zróżnicowanie poglądów, ale i zdolność osiągnięcia jednolitego stanowiska. Wskazywano na dokonane rozdzielenie najwyższych funkcji partyjnych i państwowych, na toczone dyskusje o wielu problemach „budownictwa socjalistycznego", które "bynajmniej nie mają charakteru formalnego" ${ }^{29}$. $\mathrm{W}$ „Polityce” te informacje zamieszczano głównie w niewielkiej rubryce „Kraje socjalistyczne”.

Podawane wiadomości nie były szczegółowe, ale wskazywały na dokładne śledzenie wydarzeń w CSRS: ucieczka do USA gen. Jana Szejny, problemy aktywizacji Frontu Narodowego i jednolitego kierowania życiem politycznym. Informacje te nie były utrzymane $\mathrm{w}$ alarmistycznym tonie. Życzliwie donoszono o dyskusjach o demokratyzacji w ekonomii, usunięciu biurokratycznych metod pracy, zwiększeniu praw przedsiębiorstw, decydowaniu o swym planie, autonomii zarządzania finansowego. „Płynie stąd wzrost praw ludzi pracy”, a związki zawodowe będą najważniejszymi partnerami dyrekcji ${ }^{30}$. Cytowanie („Polityka” nr 16 z 20 czerwca 1968) wypowiedzi Aleksandra Dubczeka, że przemiany nie oznaczają całkowitego zanegowania dorobku ostatnich dwudziestu lat, oraz Ludvika Svobody - że nie zmieniła się ocena lat 1945-1948 i rewolucji lutowej („Polityka” nr 21 z 25 maja 1968), wskazują na kontekst, w którym przekazywano informacje - stanowiła go „demokratyzacja systemu socjalistycznego". W prasie polskiej dostrzeżono także pojawienie się nurtu "antysocjalistycznego". Opisywano polemikę władz CSRS z tym nurtem, który podważa kierowniczą rolę partii, dyskwalifikuje jej dorobek. W CSRS toczy się ostra walka polityczna, przestaje się respektować prawo. Trzeba przeciwstawiać się rozłamowi w ,jednolitej partii marksistowskiej"31.

\footnotetext{
${ }^{29}$ R.: Po Plenum, „Polityka” 1968, nr 4 z 27 stycznia, s. 10.

${ }^{30}$ Pilne i najpilniejsze, "Polityka” 1968, nr 17 z 27 kwietnia, s. 10-11.

${ }^{31}$ H.Z.: Walka polityczna, „Polityka” 1968, nr 21 z 25 maja.
} 
Henryk Zdanowski ${ }^{32}$ wskazywał na niedocenienie w Czechosłowacji konieczności ograniczana i zwalczania sił antysocjalistycznych. KPCz nie występowała jako inicjator przemian, dopuszczono do dyskusji o utworzeniu partii opozycyjnych. Zlekceważono antypartyjne siły, bo KPCz zbyt silnie zakorzeniona jest $\mathrm{w}$ tradycji legalnego działania jak w okresie międzywojennym. Nie jest odporna na dywersję i prowokację. Odchodzeniu od naukowego socjalizmu KPCz próbuje się przeciwstawić jedynie przez polemikę, nie podkreśla niebezpieczeństwa na prawicy. Zdanowski wyraźnie formułował zarzut narastającego po prawej stronie zagrożenia dla socjalizmu w Czechosłowacji. W lipcu informowano o zniesieniu cenzury. Po publikacji w prasie czechosłowackiej oświadczenia 2000 słów narastała w prasie polskiej krytyka tolerowania „ataku na system socjalistyczny” w Czechosłowacji.

W tym kontekście tracenia kontroli nad polityczną sytuacją przez komunistów w Czechosłowacji pojawiały się w polskiej prasie informacje o zmianie polityki Pragi wobec Bonn. Była to m.in. informacja, później dementowana, o usuwaniu po czeskiej stronie barier zabezpieczających granicę z RFN. Cytowano fragment wypowiedzi Frantiszka Krigela: „Z drugiej jednak strony musimy prowadzić nowoczesną politykę, wywodzącą się z międzynarodowego podziału pracy, z przyjaźni ze wszystkimi miłującymi pokój krajami”33. Przytaczano wypowiedź dyrektora Instytutu Międzynarodowego Polityki i Gospodarki w Pradze, A. Sznejdarka, że ważniejsze od stosunków dyplomatycznych z RFN, które zapewne zostaną nawiązane w przyszłości, konieczne jest rozwijanie z nimi wzajemnych stosunków we wszystkich dziedzinach: gospodarczej, kulturalnej i naukowej ${ }^{34}$. Odbicie znajdowały pogłoski o nawiązaniu stosunków dyplomatycznych z Izraelem, możliwości podjęcia rozmów z ziomkostwem Niemców sudeckich czy też zgody na powrót „określonej liczby osób narodowości niemieckiej” wysiedlonych na mocy układu poczdamskiego ${ }^{35}$.

Nie były to informacje pierwszoplanowe, ale stanowiły stałe tło komentarzy o wydarzeniach w Czechosłowacji. Tworzyły atmosferę za-

\footnotetext{
${ }^{32}$ H. Zdanowski: W ogniu dyskusji, „Polityka” 1968, nr 25 z 22 czerwca.

33 „Polityka” 1968, nr 17 z 27 kwietnia.

${ }^{34}$ Ibidem.

${ }^{35}$ Krótka notatka w rubryce „Kraje socjalistyczne”, „Polityka” 1968, nr 29 z 20 lipca.
} 
grożenia dla Polski, okrążania jej od południa. Henryk Zdanowski, już po interwencji wojsk Układu Warszawskiego, oceniał, że istniały realne problemy, jak nierozliczenie okresu „kultu jednostki”, represje wobec osób domagających się tego, relacje między Czechami i Słowacją czy też problemy nadmiernie scentralizowanej gospodarki. Jednakże polityka KPCz doprowadziła do ataku sił rewizjonistycznych, a w zagranicznej polityce do niebezpieczeństwa porozumienia z RFN, planów zakończenia dyskusji o Monachium, haseł neutralności i nowej polityki zagranicznej, która oznaczać będzie koniec Układu Warszawskiego. „Niesłychana aktywność militarystycznych kół z Bonn w zaostrzaniu napięcia wokół CSRS była realnym faktem politycznym"36.

\section{Bohater niejednoznaczny - Francja}

Obraz Francji w polskich mediach był odmienny. Francja krytykowała politykę USA, życzliwiej nastawione były do niej kraje arabskie. W prasie polskiej wskazywano na stanowisko Francji, która wprowadziła embargo na dostawy uzbrojenia wykorzystywanego w konflikcie na Bliskim Wschodzie ${ }^{37}$. Przypominano życzliwe nastawienie Iraku do polityki de Gaulle'a na Bliskim Wschodzie, „,a szczególnie dla krytyki ekspansjonizmu syjonistycznego". W „Polityce” zamieszczono omówienie książki Jeana Raymonda Tournoux „Tragedia generała”38, eksponując zastrzeżenia i obawy de Gaulle'a wobec rosnącej roli Niemiec w Europie, ich zbrojeń, możliwego zjednoczenia i centralizacji3 ${ }^{39}$. Korzystne dla Polski było blokowanie przez nią poszerzenia Wspólnot

${ }^{36}$ Od stycznia do sierpnia, „Polityka” 1968, nr 35 z 31 sierpnia. Informacje ukazywały się zazwyczaj w rubryce „Polityki: „Kraje kapitalistyczne”. Por. ibidem, 1968, nr 7 z 17 lutego.

${ }_{37}$ T.M. Pasierbiński: „Nie cofniemy się nigdy...”, „Polityka” 1968, nr 9 z 27 stycznia, s. 9: „Rząd francuski zajmuje niezmiennie stanowisko potępiające Izrael za napaść na państwa arabskie, domaga się wycofania państwa izraelskiego z terenów zagarniętych siła, położenia kresowi wojny w tym rejonie i uznania każdego z państw tego obszaru przez wszystkie inne".

38 J.R. Tournoux: La tragédie du Général, Plon, Paris 1967.

39 "Polityka" nr 19 z 11 maja 1968. Na podstawie tej książki przygotowano także artykuł De Gaulle $i$ Wietnam („Polityka” 1968, nr 20 z 18 maja), pokazujący odmienne stanowisko de Gaulle'a wobec spraw Wietnamu i dekolonizacji. 
Europejskich. Francja stylizowana była jako pozytywna przeciwwaga polityki USA, RFN i Izraela. Niewątpliwie władze polskie czuły się ponadto zobowiązane do rewanżu za powściągliwe stanowisko władz francuskich po wydarzeniach polskiego Marca.

Przy dokładniejszym opisie wydarzeń problem stanowiły niewątpliwie analogie, które mogły się nasunąć polskiemu czytelnikowi z „własnymi” demonstracjami studenckimi. Krytykując i tłumiąc protesty studentów w Polsce, Warszawa stworzyła model ich przedstawiania, który utrudniał analizę protestów w krajach zachodnich. W opisie władz protestowały w Polsce grupy młodzieży dobrze sytuowanej, zafascynowanej kulturą Zachodu. Nie były reprezentatywne dla większości studentów, którzy chcieli się uczyć, a nie zajmować polityką. Zachowania studentów przeciwstawiane były wysiłkowi ich rodziców i narodu odbudowującego kraj.

Zakładamy, że zarówno z powyższego względu, jak i ze względu na dobre stosunki polsko-francuskie informacje $\mathrm{w}$ prasie o protestach we Francji były jeszcze na początku maja rzadkie i bardzo ogólne. Niekiedy przedstawiały de Gaulle’a w dobrym świetle, gdy mówił: „Trzeba, by uniwersytet przekształcał się i modernizował. Jestem o tym głęboko przekonany. Nie można jednak pozwolić, by wewnątrz uniwersytetu znaleźli się jego przeciwnicy i nie można dopuścić, by na ulicach zapanowały zamieszki, gdyż nie pozwoli to na dialog" ${ }^{40}$.

Nie był to tylko obraz propagandowy, ale i - wspominane przez Daniela Passenta - niedostrzeżenie narastającego we Francji kryzysu. Francja uważana była za silny kraj we Wspólnotach Europejskich, mocny gospodarczo, politycznie stabilniejszy niż RFN. Ocena Passenta ubrana była w politycznie poprawną formułę o złudnym oczekiwaniu, że „prosperujący kapitalizm w kraju uprzemysłowionym potrafi zażegnać niebezpieczeństwo konfliktu klasowego" ${ }^{41}$. Ta refleksja nie została rozszerzona na inne kraje, jedynie w odniesieniu do Francji została pogłębiona.

Sytuacja zmieniła się 21 maja, gdy we wszystkich dziennikach temat trafił na pierwsze strony. Pojawiły się krzykliwe tytuły, zdjęcia, dokładne relacje z zamieszek studenckich, sytuacji na Sorbonie, starć na ulicach

\footnotetext{
40 "Polityka” 1968, nr 20 z 18 maja.

${ }^{41}$ Pass.: "Français aidez-moi", „Polityka” 1968, nr 22 z 1 czerwca, s. 9.
} 
Paryża i innych miast francuskich, sytuacji strajkujących robotników, a następnie kampanii wyborczej i samych wyborów ${ }^{42}$. Radio i telewizja $\mathrm{w}$ swoich relacjach zamieszczały obszerne fragmenty przemówień de Gaulle'a, dotyczące sytuacji we Francji, rozwiązania francuskiego Zgromadzenia Narodowego czy szukania wyjścia z kryzysu. Typowym obrazem z tamtych wydarzeń był widok protestujących studentów niosących podobizny Mao i Che Guevary ${ }^{43}$ w rękach lub na transparentach.

W relacjach i komentarzach podkreślano napiętą atmosferę nad Sekwana, chaos panujący w całym kraju, spowodowany skalą rozruchów i demonstracji ${ }^{44}$, brak kontroli ze strony władz, brutalność policji, bałagan, nastroje niepewności i paniki ${ }^{45}$. Komentarze były, zwłaszcza $\mathrm{w}$ porównaniu ze sposobem relacjonowania sytuacji w Stanach Zjednoczonych, bardziej skąpe i lakoniczne, a zarazem znacznie bardziej wyważone. Należało jednak polskiemu czytelnikowi wyjaśnić podłoże rozruchów studenckich, a także politycznie trudny problem relacji między nimi a partiami komunistycznymi. Dopiero około 25 maja pojawiły się powściągliwe stwierdzenia, że ruch studencki znalazł poparcie części robotników, a trzy największe centrale związkowe wezwały do strajku. Uznano, że ukształtował się szerszy ruch protestu, w którym grupki anarchistyczne, prochińskie, trockistowskie i inne nie mają już większego znaczenia.

Wydaje się, że ideologiczne korzenie miał argument, iż o kompromisie i uniknięciu dalszej eskalacji konfliktu zadecydowała Francuska Partia Komunistyczna (FPK), a nie studenci i tacy studenccy radykałowie jak Daniel Cohn-Bendit, krzyczący o FPK jako „stalinowskich mętach i zdrajcach", rzucający hasła permanentnej rewolucji, odwołujący się do trockizmu i maoizmu, krytykujący społeczeństwo konsumpcyjne. To wszystko obce jest klasie robotniczej, jej interesy są inne i nie wolno

${ }^{42}$ Francja w obliczu zaostrzajacego się kryzysu politycznego, "Trybuna Ludu", 30 maja 1968, s. 1-2; V Republika na dnie, "Głos Szczeciński", 30 maja 1968, s. 2; Francja w obliczu głębokiego kryzysu społeczno-politycznego, "Gazeta Robotnicza”, 22 maja 1968, s. 1-2; Narasta kryzys we Francji, „Gazeta Krakowska”, 30 maja 1968, s. 1-2.

${ }^{43}$ A TVP, sygn. F 7804, Che Guevara...; ibidem sygn. F 913, Zarch. 12396, Oblężenie Sorbony przez strajkujacych.

${ }_{44}$ Nowa fala rozruchów w wielu miastach Francji, "Głos Olsztyński”, 13 czerwca 1968, s. $1-2$.

${ }^{45}$ Narasta kryzys we Francji, „Gazeta Krakowska”, 30 maja 1968, s. 1-2. 
było ich narażać ${ }^{46}$. Racjonalną siłą polityczną okazała się partia komunistyczna, a nie studenci. $Z$ dużym zainteresowaniem relacjonowano ich pogląd na wydarzenia, zwłaszcza obszernie opisywano ich reakcje na oficjalne wystąpienia de Gaulle'a. W prasie pojawiały się oceny czy wręcz nadzieje, że kryzys francuski „rozleje się” na inne państwa kapitalistyczne, zwłaszcza Wielką Brytanię i Włochy. Jego przyczyną miała być bowiem przede wszystkim moralna degradacja społeczeństwa, niesprawiedliwość społeczna i kryzys kapitalizmu ${ }^{47}$. Duże nadzieje wiązano z nowymi wyborami we Francji jako szansą dla "lewicy” i klasy robotniczej. Po ogłoszeniu wyników dominowało przekonanie, że słabe wyniki lewicy były rezultatem gróźb i szantażu oraz niesprawiedliwej ordynacji wyborczej ${ }^{48}$. A Francja straciła możliwość podążania "trzecią droga”, co według polskich komentatorów było jej celem jeszcze w maju i na początku czerwca 1968 roku $^{49}$.

Dostrzeżono, że Francuzi chcą być obywatelami, a de Gaulle tego nie zrozumiał. Zgodnie $\mathrm{z}$ wymaganiami polityki koncentrowano się w komentarzach na aspektach klasowo-ekonomicznych: podwyżki płac i nowe umowy zbiorowe, skrócenie czasu pracy, obniżenie wieku emerytalnego, gwarancje pracy i działalności związków zawodowych. Passent w obszernym artykule Słabość $i$ siła studentów $w^{50}$ interpretował ruchy studencie jako zjawisko w skali światowej, ale jedynie jako ruch przeciw sytuacji w systemie kapitalistycznym, przeciwko jego słabościom, niezaspokajaniu aspiracji młodych ludzi. Przeciwko militaryzmowi, społeczeństwu konsumpcyjnemu.

Środki masowego przekazu są skutecznym środkiem kształtującym opinie publiczną. Stąd kontrola nad nimi była tak ważna dla władz

${ }^{46}$ D. Fikus, D. Passent: Francja w ogniu, „Polityka” 1968, nr 23 z 8 czerwca, s. 1-10.

${ }^{47}$ R. Wojna: Nie zmienit się front walki, "Życie Warszawy", 9-10 czerwca 1968, s. 6.

${ }^{48}$ Zdobycie więckszości parlamentarnej przez gaullistów - rezultatem polityki groźby i szantażu, „Trybuna Ludu”, 1 lipca 1968, s. 1-2.

${ }^{49}$ A PR, sygn. 5548 poz. 1, 7 dni w kraju i na świecie z 22 maja 1968 roku, ibidem sygn. 5548 poz. 2, 7 dni w kraju i na świecie z 2 czerwca 1968 roku, ibidem sygn. 5548 poz. 3, 7 dni w kraju i na świecie z 9 czerwca 1968 roku.

${ }^{50}$ D. Passent: Stabość $i$ siła studentów, „Polityka” 1968, nr 26 z 2 czerwca, s. 1, 9. 
PRL. Dzięki cenzurze i wytycznym, określającym, co i w jaki sposób wolno było przedstawiać, społeczeństwo otrzymywało przygotowany wcześniej obraz wydarzeń, dopasowany do polskiej polityki zagranicznej. $Z$ telewizji, radia i prasy wyłaniał się przygnębiający obraz państw zachodnich, mających zarówno poważne problemy wewnętrzne, jak i na arenie międzynarodowej ${ }^{51}$. Negatywni bohaterowie 1968 roku to Stany Zjednoczone i Republika Federalna Niemiec. Pierwsze przedstawiono jako łamiące prawa człowieka zarówno na arenie międzynarodowej, jak i w polityce wewnętrznej, pogrążone w głębokim kryzysie społecznym i moralnym, gdzie potęga gospodarcza opiera się na niejasnych i godnych potępienia związkach czołowych polityków ze strukturami mafijnymi, a zabójstwo jest najpopularniejszym sposobem rozwiązywania problemów politycznych. Natomiast RFN traktowana była jako zagrożenie dla pokoju i europejskiego bezpieczeństwa ze względu na prowadzenie rewizjonistycznej polityki, swoje oczekiwania związane ze zbrojeniami i na zachodnioniemiecki sprzeciw wobec rozbrojenia. Na tym tle wyróżnia się sposób przedstawiania Francji, związany $\mathrm{z}$ odmiennością $\mathrm{w}$ sposobie prowadzenia przez nią polityki zagranicznej, a zwłaszcza ze względu na krytykowanie przez Paryż USA, jego zastrzeżenia wobec rosnącej roli Niemiec w Europie, a także blokowanie rozszerzenia Wspólnot Europejskich. Pozostałe państwa zachodnie gościły w 1968 roku na łamach polskiej prasy, w polskim radiu i telewizji sporadycznie.

\section{Abstract \\ The events of 1968 in the West, as portrayed in the Polish media}

The mass communication media are one of the most effective means of influencing public opinion. It was for this reason that exercising control over them was so important for the authorities in the People's Republic of Poland. Thanks to the censorship and the guidelines as to what could be presented, and how, society received a pre-set image of events, subordinated to Poland's foreign policy. Television, radio and the print media communicated a depressing vision of the Western states coping with gravely serious problems, both domestic and in

${ }^{51}$ A TVP, sygn. P 6750, Zbuntowani znad Tamizy. 
foreign policy. In 1968, there were two central negative characters, the USA and the FRG. The USA was presented as a state breaching human rights, both in the international arena and in its domestic policy, immersed in deep social and moral problems, with political assassinations, employed as a dubious method of solving political problems being pointed to as evidence of that situation, and with the murky ties of leading politicians to the mafia structures providing the basis of the economic success so envied by other nations, including the Poles. The RFG, in its turn, was treated as a real threat to European and global peace and security, because of its running a revisionist policy, its expectations in regard of arming the country, and the West German opposition to disarmament. Against this backdrop, only the manner in which France was presented was markedly distinct, this being in view of the differences in the manner by which it carried out its foreign policy and, in particular because of its criticism of the USA and its reservations regarding Germany's growing role in Europe, as well as its blocking of the enlargement of the European Communities. The other Western States were the focus of attention on the part of the Polish press, radio and television only occasionally. 